\title{
The effect of organizational commitment and Cost management knowledge on the relationship between budget participation and managerial performance
}

\author{
Laras Dwi Novlina, Mirna Indriani*, Indayani \\ Universitas Syiah Kuala, Banda Aceh, Indonesia \\ *Corresponding author email: mirna_indriani@unsyiah.ac.id
}

\section{A R T I C LE I N F O}

Article history:

Available online

\section{Keywords:}

Budget participation, organizational commitment, CMK, managerial performance

\section{DOI:}

https://doi.org/10.20885/jaai.vol24.i $\underline{\text { ss1.art6 }}$

\section{A B S T R A C T}

The purpose of this study is to examine the effect of organizational commitment and cost management knowledge on the relationship between budget participation and managerial performance. The data used in this study collected by distributed questionnaires to 700 managers work in manufacturing companies in Indonesia. The sample used in this study consists of 98 managers who involve in budgetary participation. Data were analyzed by using the Structural Equation Model (SEM) based Partial Least Square (PLS) with WarpPLS 6.0 software. The result of this study represent that budgetary participation has a positive effect on managerial performance and cost management knowledge moderate the relationship between budgetary participation and managerial performance, while organizational commitment has no effect on the relationship between budgetary participation and managerial performance.

\section{Introduction}

Good performance is increasingly crucial for the company to obtain to maintain their business. Santos et al. (2014) and Farahmita (2016) state that organizational performance is reflected by managerial performance. As stated by Patterson et al. (2003), individual performance is the most influential factor that affects firm performance. Hence, managers need to have a good performance to support organizational performance overall. Managerial performance defined as the results of work or achievement of individuals in the organization in terms of carrying out management functions namely planning, investigation, evaluation, coordination, supervision, staffing, negotiation, and representative. In general managerial performance becomes an outcome variable in accounting and management research that is often associated with the budgeting process. Therefore, the budgeting process is very important in the company (Oluwalope \& Sunday, 2017; Savitri et al., 2015).

Lau et al. (2018) stated that the involvement of individuals in the budgeting process is a key factor in budgeting. The involvement of individuals in the company from various managerial levels in the budgeting process and have an influence on its product, budget, is called budgetary participation. The concept of budget participation was introduced by Milani in 1975 in an article published in The Accounting Review with the title"The Relationship of Participation in Budget-Setting to Industrial Supervisor Performance and Attitudes: A Field Study (Milani, 1975). Since then, budget participation has been studied extensively and still going on the research agenda (Derfuss, 2016) and it becomes at the very researched theme in management accounting literature (Lau et al., 2018) which attracted the attention of many researchers (Cheng et al., 2014). Likewise, research that links it with performance (Karakoc \& Ozer, 2016).

Derfuss (2016) argues the relationship between budgetary participation and performance does not occur directly by psychological or agency factors but is supported or mediated by other variables. Accordingly, many studies link budgetary participation and managerial performance with the contingency approach. Contingency variables that used in the studies such as Cost management knowledge (CMK) (Agbejule \& Saarikoski, 2006; Farahmita, 2016; Santos et al., 2014; Savitri et al., 2015), organizational commitment (Arifuddin et al., 2017; Gunawan \& Santioso, 2015; Murwaningsari, 2008; Nuraini \& Rosyati, 2012), motivation (Gunawan \& Santioso, 2015), management accounting system (Indriani \& Nadirsyah, 2015), ITEC, activity-based costing (Maiga et al., 2014).

The studies conducted by Agbejule and Saarikoski (2006) and Farahmita (2016) use the model of performance theory by Blumberg and Pringle (1982) as a theoretical basis in examining the relationship between budgetary participation and managerial performance which states that individual performance is influenced by 
capacity, willingness, and opportunities. The result of Agbejule and Saarikoski (2006) and Farahmita (2016) studies show that CMK strengthens the relationship. Budget participation will have a positive effect on managerial performance when managers have higher CMK. (Agbejule \& Saarikoski, 2006). CMK is useful for managers in budget preparation to control inefficient costs (Hasan et al., 2018). So, the resulting budget expected to be more accurate. Santos et al. (2014) and Savitri et al. (2015) also use CMK as a moderating variable and found similar results. Hasan et al. (2018) also show that CMK can moderate the relationship of budget control which includes budget participation on managerial performance.

With another contingency variable, a study conducted by Gunawan and Santioso (2015) uses organizational commitment as a moderating variable to examine the relationship budget participation with managerial performance. The study indicates the positive influence which consistent with the studies conducted by Sumarno (2005), Murwaningsari, (2008), Irfan et al. (2016), dan Arifuddin et al. (2017). Organizational commitment can comfirm the relationship between budget participation and managerial performance. Organizational commitment as an affective attitude is considered as a more stable predictor in looking at employee turnover, attendance, and performance (Mercurio, 2015; Wombacher \& Felfe, 2017).

The purpose of this study is to examine the effect of organizational commitment and CMK on the relationship between budget participation and managerial performance. This study based on the model of performance theory from Blumberg and Pringle (1982) to test the effect of budget participation on managerial performance which is moderated by organizational commitment and CMK. A modification from previous research by Farahmita (2016) conduct in this research with the difference in willingness dimension, this study uses organizational commitment to replace job satisfaction which is used in previous research as an attitude and reflects the willingness of managers. The next difference is in the object of research, where this study uses manufacturing companies throughout Indonesia while previous research was conducted in Jakarta and Depok. The researcher focuses on the manufacturing industry sector because the cost structures are more complex than other companies that are not manufacturing such as services and trade. In companies with more complex cost structures requires a special understanding of costs at each level of the organization. Therefore, manufacturing company managers are very relevant to test the proposed research hypotheses.

\section{Literature Review}

\section{Theory of Work Performance}

Blumberg and Pringle (1982) on his research reveal a theoretical framework that states three things affect individual performance in the organization, namely opportunity, capacity, and willingness. The model is as the following; Performance $=\mathrm{f}$ (opportunity $\times$ capacity $\times$ willingness).

1) The dimension of opportunity that interacts together with the dimension of capacity and willingness can derive performance improvements. This dimension refers to technical system components, such as leadership style, procedure, equipment, inventory, and organizational policies. 2) The dimension of capacity refers to capabilities or psychological and cognitive abilities that make it easier for individuals to work effectively. This dimension can be reflected by ability, knowledge, intelligence, educational level, age, health condition, motoric skill, and other similar aspects. 3) The dimension of willingness refers to psychological and emotional characteristics that affect individuals in doing their work. This dimension can be reflected by motivation, job satisfaction, personality, attitudes, norms, values, work status, self-image, and other characteristics.

This theory developed by a model that says performance is a result of a combination of ability and motivation. The model is widely used, but its capability in calculating additional variations in performance is often unsuccessful (Blumberg \& Pringle, 1982). This performance model has been used in several studies related to budget participation, such as Agbejule \& Saarikoski (2006), Santos et al. (2014), and Farahmita (2016) in examining the relationship between budget participation and managerial performance.

In this study the dimension of opportunity is represented by a budgetary participation variable that reflects company organization policies, the CMK variable is used to represent the dimension of individual capacity, and the organizational commitment variable is used to represent the dimension of willingness that reflect individual attitudes. With the contingency approach, the variable organizational commitment and cost of management knowledge are used as moderating variables in looking at the relationship of budgetary participation with managerial performance.

\section{The Effect of Budget Participation on Managerial Performance}

Budget participation in the process whereby managers are involved in budget setting (Brink et al., 2018) and have influence on the budget (Milani, 1975; Shields \& Shields, 1998). The budget is arranged as a management tool to perform management functions, that is planning, coordinating, and controlling (Chong \& Strauss, 2017). Involving the participation from various level of managers in budgeting will increase the quality of budget 
influence the psychological effect of individuals such as increase morale and self-efficacy (Brink et al., 2018; Derfuss, 2016; Yuliansyah \& Khan, 2017) and create motivation in achieving budget targets (Hariyanti et al., 2015; Wong-On-Wing et al., 2010; Zainuddin \& Zainal, 2012).

On the other hand, managerial performance is a measure of the level of achievement that obtains by managers in perform management functions (Derfuss, 2016; Hariyanti et al., 2015; Mahoney et al., 1965). In the implementation of management functions, information is needed in making decisions, therefore management's ability in obtaining the accurate information is important to support decision-making that can enhance managerial performance (Rokhman, 2017). Thus, budget participation supports management functions such as planning, implementation, and controlling on target. Based on these statements, it can be said that the budget participation process that improves budget quality can affect managerial performance as measured by its achievement of management functions were the key factors of management functions implemented and its success is through the budget. In addition, with budget participation, individual motivation in work will also increase which then will increase the achievement of budget targets and lead to increased performance (Ernis et al., 2017; Hariyanti et al., 2015; Wong-On-Wing et al., 2010; Zainuddin \& Zainal, 2012).

The relationship between the success of the budget compiled in a participative way with the achievement of budgetary goals and managerial performance has been found in many previous studies. Murwaningsari (2008), Noor and Othman (2012), Saraswati and Aisyah (2015), Gunawan and Santioso (2015), Hariyanti et al. (2015), Boujelbene and Affes (2015), Ernis et al. (2017), and Oyewo and Adyeye (2018) have proved that budget participation can enhance managerial performance. Further studies by Lameira Silva et al. (2020) show budgetary participation directly and positively influences managerial attitudes toward budgeting, job satisfaction, and controllers' performance in budget activities. Based on the theory and previous studies, a hypothesis is derived: $\mathrm{H} 1$ : Budget participation has a positive effect on managerial performance.

\section{The Effect of Organizational Commitment on The Relationship between Budget Participation and Managerial Performance}

Organizational commitment is defined as the emotional bond of an individual in accepting the values and goals of the organization and willing to devote himself to the organization. They have a high willingness to remain in the organization despite experiencing dissatisfaction (Robbins \& Judge, 2017). Organizational commitment can influence the involvement of individuals in the organization. Those who have high commitment will be more often to involve in organizational activities. Accordingly, as Porter et al. (1974) own promised that an individual's commitment to his organization has an influence on motivation in participating. With the opportunity to be involved in the budgeting process, this will increase trust and ego involvement that makes individuals more receptive and committed to the result of the budget decision (Arifuddin et al., 2017).

Individuals who have organizational commitment will strive to make efforts that benefit the interests of the organization and also strive to pursue organization goals (Mowday et al., 1979) High-level organizational commitment of managers will make them have strong willingness to work in order to achieve budget targets that can improve their managerial performance (Nuraini \& Rosyati, 2012). Based on Blumberg and Pringle's (1982) theory of work performance, and individual willingness which reflected on attitude and accompanied by the opportunity to implement attitude which is commitment can support performance improvement.

Several previous studies have been proved organizational commitment influences the relationship between budget participation and managerial performance. Sumarno (2005), Murwaningsari (2008), Nuraini and Rosyati (2012), Gunawan and Santioso (2015), and Arifuddin et al. (2017) on their research found a positive relationship of organizational commitment in strengthening the relationship of budgetary participation with managerial performance.

$\mathrm{H} 2$ : The higher the level of organizational commitment, the more positive budget participation influences managerial performance.

\section{The Influence CMK on The Relationship between Budget Participation and Managerial Performance}

CMK shows the knowledge possessed by a manager regarding the cost management process in the company. Knowing a variable in an organization allows individuals to use it to perform better in their fields (Santos et al., 2014). Capability in acquiring and applying knowledge in solving problems is a cognitive ability has by an individual (Colquitt et al., 2017).

Managers who have the capacity to be knowledgeable about cost management will make it easier to make decisions and make their works more effectively. Applying CMK in preparing a budget can influence the decision on-budget results. As Shields and Young (1994) stated, CMK can support managers understand business processes and organizational activities comprehensively. Thus it will make managers able to enhance process improvement that is cost-beneficial and it's an important element in achieving budget (Savitri et al., 
2015). The resulting budget decision will be better with more accurate information. Otherwise, without CMK in budgeting processes lead to less accurate decision making (Hasan et al., 2018).

A study conducted by Hunton et al. (2001) shows that the factors of knowledge, skill, and experience regarding management accounting affect work performance. Technical knowledge about management accounting can give the successful performance of beginner management accountants. In the context of budgeting, the cost of management knowledge which is part of management accounting is a relevant knowledge to use. Agbejule and Saarikoski (2006) that CMK is an important factor in effective budget participation. The high level of CMK in managers involved in the budgeting process can lead to enhance performance.

Agbejule and Saarikoski (2006), Santos et al. (2014), Farahmita (2016), dan Savitri et al. (2015) show the moderating role of $\mathrm{CMK}$ on the relationship between budget participation and managerial performance. They found that the increase in CMK on managers has a positive influence on the relationship between budget participation and managerial performance.

H3: The higher the level of CMK, the more positive budget participation influences managerial performance.

\section{Research Method}

\section{Population and Sample}

The sample in this study was managers work in manufacturing companies in Indonesia who involve in the budgeting process. The manager of the manufacturing company was chosen because the manufacturing company was very involved with complex cost decisions such as raw material costs, production costs, finishing costs, and environmental costs associated with the waste of production. The sampling technique in this study was carried out by nonprobability sampling with a convenience sampling method. This method was chosen because the population is very large and the number is uncertain and it is not possible to include all managers.

This study uses primary data sources. The method of collecting the research data is through an online questionnaire. Online questionnaires are sent to the corporate secretary e-mails of each manufacturing company listed on the IDX by attaching a questionnaire link and a request to spread the questionnaire to the research respondents. In addition, the questionnaire link was also sent randomly to managers of manufacturing companies in Indonesia whose contacts were obtained through LinkedIn.

\section{Measurement of Variables}

\section{Managerial performance}

Managerial performance measurement using self-rating on management functions. The management functions include planning, investigation, coordination, evaluation, supervision, staffing, negotiation, representation, and overall performance (Mahoney et al. 1965) The measurement consisted of 9 indicators namely and using a 7point Likert scale which has been widely used in previous studies (Indriani \& Nadirsyah, 2015; Maiga et al., 2014; Nuraini \& Rosyati, 2012; Wong-On-Wing et al., 2010)

\section{Budget participation}

Budget participation is a process that involves various managerial levels in budgeting (Brink et al., 2018) and influences the budget (Shields \& Shields, 1998). This variable is measured by a 7-point Likert scale consisting of 6 indicators from Milani (1975) that has been used by many previous studies (Jermias \& Yigit, 2013; Maiga et al., 2014; Farahmita, 2016; Ernis et al., 2017).

\section{Organizational commitment}

Organizational commitment is the level at which individuals support the organization and its objectives and have a wish to remain as a member of the organization (Robbins \& Judge, 2017). Organizational commitment is measured by Organizational Commitment Questionnaire (OCQ) developed by Mowday et al. (1979) which has been widely used in previous studies such as Sumarno (2005), Nuraini and Rosyati (2012), Selvina and Yuliansyah (2015), and Irfan et al. (2016). OCQ consists of 9 indicators and measured by 7 items Likert scale.

\section{CMK}

CMK is measured based on cost management style developed by Shields and Young (1994) where Agbejule and Saarikoski (2006) used the management style and developed it into an indicator for CMK variable. This measurement then used in research conducted by Santos et al. (2014) and Farahmita (2016). Measurement of this variable uses 6 questions with 7 items Likert-scale. The questions are around the cost of management knowledge in general. A summary of the measurement of variables is presented in table 1 . 
Table 1. A summary of the measurement of variables

\begin{tabular}{|c|c|c|c|c|}
\hline & Definisi & & Indikator & Sumber \\
\hline $\begin{array}{l}\text { Managerial } \\
\text { Performance }\end{array}$ & $\begin{array}{l}\text { Manager's } \\
\text { performance in } \\
\text { carrying out } \\
\text { management } \\
\text { functions }\end{array}$ & $\begin{array}{l}\text { MP1 } \\
\text { MP2 } \\
\text { MP3 } \\
\text { MP4 } \\
\text { MP5 } \\
\text { MP6 } \\
\text { MP7 } \\
\text { MP8 } \\
\text { MP9 }\end{array}$ & $\begin{array}{l}\text { Planning } \\
\text { Investigating } \\
\text { Coordinating } \\
\text { Evaluating } \\
\text { Supervising } \\
\text { Staffing } \\
\text { Negotiating } \\
\text { Representative } \\
\text { Overall Performance }\end{array}$ & $\begin{array}{l}\text { Mahoney } \\
\text { (1965); } \\
\text { Agbejule \& } \\
\text { Saarikoski } \\
\text { (2006); } \\
\text { Maiga et al. } \\
\text { (2014) }\end{array}$ \\
\hline $\begin{array}{l}\text { Budget } \\
\text { participation }\end{array}$ & $\begin{array}{l}\text { The process by } \\
\text { which managers } \\
\text { are involved, } \\
\text { influences, and } \\
\text { controls the } \\
\text { budget. }\end{array}$ & $\begin{array}{l}\text { BP1 } \\
\text { BP2 } \\
\text { BP3 } \\
\text { BP4 } \\
\text { BP5 } \\
\text { BP6 }\end{array}$ & $\begin{array}{l}\text { The extent of involvement in setting the budget } \\
\text { The reasoning of budget revisions } \\
\text { Frequency of requests, opinions, and/or suggestions about } \\
\text { the budget. } \\
\text { Frequency of requests, opinions, and/or suggestions about } \\
\text { the budget. } \\
\text { Importance of contribution to the budget } \\
\text { Frequency of requests, opinions, and/or suggestions sought } \\
\text { by your superior }\end{array}$ & $\begin{array}{l}\text { Milani } \\
(1975) ; \\
\text { Agbejule \& } \\
\text { Saarikoski } \\
\text { (2006); } \\
\text { Chong \& } \\
\text { Strauss } \\
(2017)\end{array}$ \\
\hline $\begin{array}{l}\text { Organizational } \\
\text { Commitment }\end{array}$ & $\begin{array}{l}\text { The individual-level } \\
\text { supports the } \\
\text { organization and } \\
\text { its goals and has a } \\
\text { desire to maintain } \\
\text { its membership in } \\
\text { the organization. }\end{array}$ & $\begin{array}{l}\text { OC1 } \\
\text { OC2 } \\
\text { OC3 } \\
\text { OC4 } \\
\text { OC6 } \\
\text { OC7 } \\
\text { OC } 8\end{array}$ & $\begin{array}{l}\text { "I am willing to put in a great deal of effort beyond that } \\
\text { normally expected to help this organization be successful } \\
\text { I talk up this organization to my friends as a great } \\
\text { organization to work for. } \\
\text { I would accept almost any type of job assignment to keep } \\
\text { working for this organization. } \\
\text { I find that my values and the organization's values are very } \\
\text { similar. } \\
\text { I am proud to tell others that I am part of this organization. } \\
\text { This organization inspires the very best in me in the way of } \\
\text { job performance. } \\
\text { I am extremely glad that I chose this organization to work } \\
\text { for over others I was considering at the time I joined. } \\
\text { For me, this is the best of all possible organizations for } \\
\text { which to work. } \\
\text { I care about the fate of this organization." }\end{array}$ & $\begin{array}{l}\text { Mowday et } \\
\text { al. (1979); } \\
\text { Sumarno } \\
\text { (2005); } \\
\text { Irfan et al. } \\
\text { (2016 }\end{array}$ \\
\hline CMK & $\begin{array}{l}\text { The level of } \\
\text { knowledge an } \\
\text { individual has } \\
\text { regarding cost } \\
\text { management. }\end{array}$ & $\begin{array}{l}\text { CMK1 } \\
\text { CMK2 } \\
\text { CMK3 } \\
\text { CMK4 }\end{array}$ & $\begin{array}{l}\text { "My job experience includes assignments in which I have } \\
\text { had formal responsibility for managing } \\
\text { profits } \\
\text { I have always worked in units in which the primary measure } \\
\text { of performance was profits } \\
\text { I have a lot of experience in managing costs } \\
\text { I manage costs by comparing the amounts spent on various } \\
\text { items against the amounts for each of } \\
\text { those items in the budget. } \\
\text { I manage costs by examining whether the total amount } \\
\text { spent on several items has yielded a good outcome. } \\
\text { My style of managing costs is to watch each line item of the } \\
\text { budget very carefully } \\
\text { I evaluate the outcomes of my work and the costs involved" }\end{array}$ & $\begin{array}{l}\text { Agbejule \& } \\
\text { Saarikoski } \\
\text { (2006); } \\
\text { Farahmita } \\
(2016)\end{array}$ \\
\hline
\end{tabular}

\section{Analysis Method}

The data analysis method used to test the hypothesis in this study is using SEM (Structural Equation Model) based PLS (Partial Least Square) with WarpPLS 6.0 software. The PLS approach is one of the SEM statistical methods based on variants that serve to address specific problems that occur in multiple regression, such as the symptoms of multicollinearity, the small size of the study sample, and the presence of missing data. 


\section{Results and Discussion}

\section{Descriptive Statistic}

The characteristics of respondents in this study are shown in table 2. Characteristics of respondents describe gender, age, educational level, position, and length of work respondents.

Table 2. Research Respondent Characteristics

\begin{tabular}{lcc}
\hline \multicolumn{1}{c}{ Respondent Characteristics } & Total & Frequency \\
\hline Gender: & & \\
Male & 87 & $88,8 \%$ \\
Female & 11 & $11,2 \%$ \\
Age: & & \\
20-29 years & 27 & $27,6 \%$ \\
30-39 years & 43 & $43,9 \%$ \\
40-49 years & 21 & $22,4 \%$ \\
> 50 years & 7 & $7,1 \%$ \\
Educational Level: & & \\
High School & 2 & $2,0 \%$ \\
Diploma Degree & 2 & $2,0 \%$ \\
Bachelor Degree & 74 & $75,5 \%$ \\
Master Degree & 18 & $18,4 \%$ \\
Doctoral Degree & 2 & $2,0 \%$ \\
Position: & & \\
General Manager & 12 & $12,3 \%$ \\
Branch Manager & 6 & $6,1 \%$ \\
Financial, Accounting \& Tax Manager & 7 & $7,1 \%$ \\
Sale Manager & 21 & $21,4 \%$ \\
Key Account Manager & 4 & $4,1 \%$ \\
Human Resource Manager & 2 & $2,0 \%$ \\
Production \& Operational Manager & 8 & $8,2 \%$ \\
Marketing Manager & 2 & $2,0 \%$ \\
Business Development Manager & 3 & $3,1 \%$ \\
Others & 33 & $33,7 \%$ \\
Length of Work: & & \\
1-5 years & & $40,8 \%$ \\
6-10 years & 40 & $20,4 \%$ \\
11-15 years & 20 & $20,4 \%$ \\
16-20 years & 20 & $8,2 \%$ \\
> 20 years & 8 & $10,2 \%$ \\
\hline
\end{tabular}

Hereafter, the following descriptive statistics are shown in each research variable.

Table 3. Descriptive Statistics

\begin{tabular}{lcc}
\hline \multicolumn{1}{c}{ Variable } & Mean & Standard Devices \\
\hline Budget Participation (BP) & 5,561 & 1,172 \\
Organizational Commitment (OC) & 6,139 & 0,891 \\
CMK (CMK) & 5,792 & 0,993 \\
Managerial Performance (MP) & 6,015 & 0,868 \\
\hline
\end{tabular}

This study uses a 7-point Likert scale. Based on table 3, budget participation shows an average value of 5.561 with a standard deviation of 1.172 which indicates the participation of managers who are respondents in high budget participation. The average value of organizational commitment shows the number 6.139 with a standard deviation of 0.891 which indicates the level of organizational commitment of high respondents. CMK also shows a fairly high average value of 5.792 with a standard deviation of 0.993 . This shows that the level of cost of management knowledge owned by respondents is quite good. Furthermore, the managerial performance also shows an average value that is close to the highest value of 7 which is 6.015 with a standard deviation of 0.868 . That is, respondents have excellent managerial performance. 


\section{Data Analysis Result}

\section{Outer Model Test}

Evaluation of the outer model illustrates the relationship between constructs and indicators that form latent variables. The outer model test in this study includes convergent validity, discriminant validity, reliability indicators, and composite reliability. Some indicators in the research, namely OC.3, CMK.1, CMK.2, MP3, and MP7, were eliminated from processing because they did not fulfill the rule of thumb loading factor $>0.6$ (Ghozali \& Latan, 2017). The following results of the outer model test can be seen in table 4.

Table 4. Outer Model Test Results

\begin{tabular}{|c|c|c|c|c|c|}
\hline Variable & Indicator & $\begin{array}{l}\text { Loading Factor } \\
\quad \geq 0,60\end{array}$ & $\begin{array}{c}\text { CR } \\
>0,70\end{array}$ & $\begin{array}{l}\text { AVE } \\
>0,50\end{array}$ & $\sqrt{\mathrm{AVE}}$ \\
\hline \multirow[t]{6}{*}{ Budget Participation (BP) } & BP1 & 0,851 & 0,912 & 0,635 & 0,797 \\
\hline & BP2 & 0,602 & & & \\
\hline & BP3 & 0,844 & & & \\
\hline & BP4 & 0,850 & & & \\
\hline & BP5 & 0,754 & & & \\
\hline & BP6 & 0,849 & & & \\
\hline \multirow{8}{*}{$\begin{array}{l}\text { Organizational Commitment } \\
\text { (OC) }\end{array}$} & OC1 & 0,735 & 0,945 & 0,682 & 0,826 \\
\hline & OC2 & 0,800 & & & \\
\hline & OC4 & 0,817 & & & \\
\hline & OC5 & 0,880 & & & \\
\hline & OC6 & 0,854 & & & \\
\hline & OC7 & 0,833 & & & \\
\hline & OC8 & 0,850 & & & \\
\hline & OC9 & 0,830 & & & \\
\hline CMK & CMK3 & 0,762 & 0,931 & 0,730 & 0,855 \\
\hline \multirow[t]{4}{*}{$(\mathrm{CMK})$} & CMK4 & 0,925 & & & \\
\hline & CMK5 & 0,889 & & & \\
\hline & CMK6 & 0,832 & & & \\
\hline & CMK.7 & 0,856 & & & \\
\hline Managerial Performance & MP1 & 0,815 & 0,886 & 0,529 & 0,727 \\
\hline \multirow{6}{*}{ (MP) } & MP2 & 0,734 & & & \\
\hline & MP4 & 0,665 & & & \\
\hline & MP5 & 0,624 & & & \\
\hline & MP6 & 0,757 & & & \\
\hline & MP8 & 0,609 & & & \\
\hline & MP9 & 0,852 & & & \\
\hline
\end{tabular}

From table 4 above, it can be seen the CR value for budget participation variable (0.912), organizational commitment (0.945), CMK (0.931), and managerial performance $(0.886)$ which is very good at $>0.70$. So, it can be deduce that the indicators of each construct used from this research instrument are reliable. Then, based on the table above, it is known that the AVE value for each variable is $>0.50$ so that it can be said convergent validity which tests the correlation between indicators to measure the construct for all variables already good. In addition, the $\sqrt{ } \mathrm{AVE}$ value seen to meet discriminant validity criteria has also been very good, where all variables have greater $\sqrt{ }$ AVE values than correlation values between constructs (Ghozali \& Latan, 2014: 95).

\section{Inner Model Test}

After testing the validity and reliability test in the outer model, an inner model evaluation conducted which aims to find out or foretell the relationship between latent variables by looking at how much variance can be explained and to find out the significance value of p-value (Ghozali \& Latan, 2014:91). The goodness of fit results obtained in the inner model test can be seen in Table 5 below.

Based on the data shown in table 5 , it is known that the model has a good fit model. This can be seen in the APC p-value (Average R-Square), ARS (Average R-Squared), and AARS (Average Adjusted R-Squared) $<0.05$. APC values (0.188), ARS (0.202), and AARS (0.176) also show good numbers. Furthermore, the AVIF (Average Block Variance Inflation Factor) and AFVIF (Average Full Collinearity VIF) values obtained are below 3.3, which indicates that there is no multicollinearity problem between independent (exogenous) variables. The goodness of 
Fit shows a value of 0.348 which means that the fit model is included in the middle category. SPR (Sympson's Paradox), RSCR (R-Squared Contribution Ratio), SSR Statistics (Suppressions Ratio), and NLBCDR (Nonlinear Bivariate Causality Direction Ratio) all show a value of 1,000 which means there is no problem of causality in the model.

Table 5. Inner Model Test

\begin{tabular}{llcc}
\hline \multicolumn{1}{c}{ Indicator } & \multicolumn{1}{c}{ Fit Level Target } & Estimation Results & Fit Level \\
\hline APC & $>0,05$ & APC $=0,188$ & Good Fit \\
& $p$ value $\leq 0,05$ & $p$ value $=0,013$ & \\
ARS & ARS $=0,202$ & Good Fit \\
& $p$ value $\leq 0,05$ & $p$ value $=0,009$ & Good Fit \\
AARS & $>0,05$ & AARS $=0,176$ & Good Fit \\
& $p$ value $\leq 0,05$ & $p$ value $=0,018$ & Good Fit \\
AVIF & $\leq 3,3$, however $\leq 5$ still acceptable & 1,729 & Menengah \\
AFVIF & $\leq 3,3$, however $\leq 5$ still acceptable & 1,865 & Good Fit \\
GoF & $\geq 0,36$ (big) & 0,348 & Good Fit \\
SPR & $\geq 0,25$ (middling) $\geq 0,10$ (kecil) & & Good Fit \\
RSCR & Rule of thumb $=1$, however $\geq 0,7$ still & 1,000 & Good Fit \\
SSR & acceptable & 1,000 & 1,000 \\
NLBCDR & 1, however $\geq 0,7$ still acceptable & 1,000 &
\end{tabular}

\section{Hypothesis Test Results}

The results of the structural model on the effect of budget participation on managerial performance with the role of organizational commitment and cost of management knowledge as moderating variables are shown in the following figure 1.

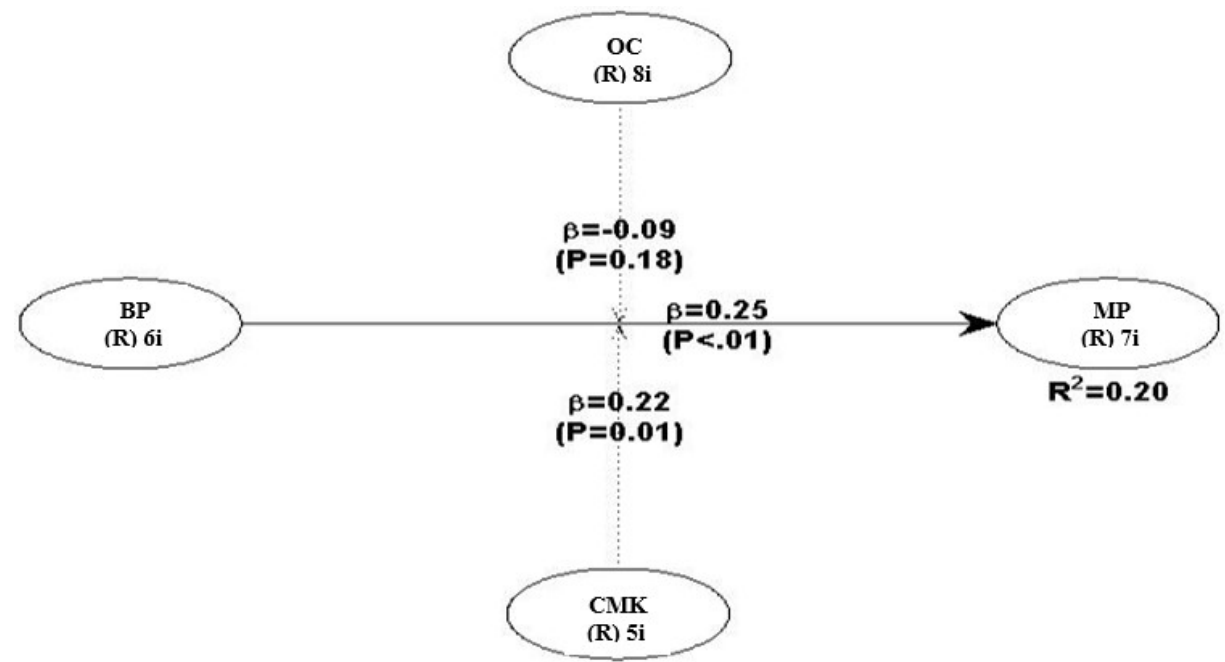

Figure 1. Structural Model Result

Table 6 below shows path coefficient, p-value, effect size, R-squared, Adjusted R-Squared, and QSquared which are seen in assessing the research hypothesis.

Table 6. Hypothesis Test Results

\begin{tabular}{|c|c|c|c|}
\hline Variable & Path coefficient & $\mathrm{p}$-value & Effect size \\
\hline $\mathrm{BP}$ & 0,247 & 0,005 & 0,088 \\
\hline $\mathrm{BP} * \mathrm{OC}$ & $-0,092$ & 0,177 & 0,029 \\
\hline $\mathrm{BP} * \mathrm{CMK}$ & 0,224 & 0,010 & 0,085 \\
\hline \multicolumn{4}{|l|}{ R-squared $=0,202$} \\
\hline \multicolumn{4}{|l|}{ Adjusted R-squared =0,176 } \\
\hline Q-squared $=0,216$ & & & \\
\hline
\end{tabular}


Based on table $6, \mathrm{R}^{2}$ value indicates a number of 0.202 , which means that managerial performance variable is influenced by budget participation, the interaction of budget participation with organizational commitment, and interaction of budget participation with the cost of management knowledge for $20.2 \%$. The value of $\mathrm{Q}^{2}$ on endogenous variable managerial performance shows a number of 0.216 . This shows that the model has predictive relevance.

Based on the effect size value of each variable, it is known that the proportion of the budget participation variable to managerial performance is 0.088 , which means that $8.8 \%$ managerial performance is influenced by budget participation. The effect size value of the first moderating variable which is the interaction between budget participation and organizational commitment amounting to 0.029 or $2.9 \%$. Furthermore, the interaction between budget participation and cost of management knowledge can explain managerial performance by $8.5 \%$.

Budget participation has a path coefficients value of 0.247 and a p-value of $0.005(<0.05)$, so that $\mathrm{H} 1$ is supported. Therefore, it can be concluded that the variable budget participation has a positive effect on managerial performance. The results of this study are in line with the results of research conducted by Murwaningsari (2008), Noor and Othman (2012), Saraswati and Aisyah (2015), Savitri et al. (2015), Gunawan and Santioso, (2015), Hariyanti et al. (2015), and Ernis et al. (2017) which show the positive influence of budget participation on managerial performance directly. Budget participation can increase understanding, effort, and motivation of managers in achieving budget targets and can improve the quality of the budget which will lead to enhance managerial performance of managers.

The interaction of budget participation with organizational commitment has a path coefficients value of 0.092 and p-value of 0.177 ( $>0.05)$, so that $\mathrm{H} 2$ cannot be supported. Therefore, it can be concluded that organizational commitment is not able to moderate the relationship between budget participation and managerial performance. The results of this study are in line with Rudhianto (2010) and Yogantara and Wirakusuma (2013). However, these results cannot support the result of the research conducted by Sumarno (2005), Murwaningsari (2008), Gunawan and Santioso (2015), Irfan et al. (2016), and Arifuddin et al. (2017). Based on these results, the organizational commitment of managers involved in budget participation is not able to have a positive impact on improving managerial performance. Researchers argue this can because there are things that cause managers cannot express the commitment they have when participating in budgeting to achieve performance.

The interaction of budget participation with management cost knowledge has a path coefficients value of 0.224 and a p-value of $0.010(<0.05)$, so that $\mathrm{H} 3$ can be supported. Therefore, it can be concluded that the cost of management knowledge is able to moderate the relationship between budget participation and managerial performance. This result is in line with the results of research conducted by Agbejule and Saarikoski (2006), Santos et al. (2014), Savitri et al. (2015), and Farahmita (2016). The level of knowledge can influences how managers work and make decisions that can ultimately affect their performance. Especially important for managers who involve in budgeting processes to have CMK. Santos et al. (2014) in their study stated that the better a manager is trained in issues related to cost management and the encouragement of budget participation, the better their performance can contribute to overall organizational performance. Thus this result supports Blumberg and Pringle (1982) performance theory where individual capacity factors combined by opportunities in this case budget participation can encourage improvement in individual performance.

\section{Conclusion}

This study investigates the effect of budget participation on managerial performance by the moderating role of organizational commitment and CMK in managers activity in manufacturing companies in Indonesia. The results showed budget participation had a positive influence on managerial performance. The cost of management knowledge in this study proved to be able to moderate the influence of budget participation on managerial performance. This shows the capacity of individuals supports the budgeting process in achieving performance. However, the moderating role of organizational commitment to the influence of the relationship budget participation and managerial performance was found to be insignificant. Organizational commitment combined with budget participation in this study is considered not the best fit. Researchers consider organizational commitment to has a direct effect on managerial performance.

The implications of this research can be useful for companies to maintain and improve budget participation policies and also for managers to maintain and improve the level of CMK. This can be useful in improving managerial performance that can support the improvement of overall company performance.

This study has several limitations including the use of research results that are difficult to generalize with a limited number of samples in this study from a very large population. The next study can use a wider number of respondents to make research results more generalizable. Furthermore, the measurement of variables in this study is carried out subjectively. Future research can use additional methods such as observation and interviews or qualitative approach so that the results obtained can be more objective and credible. 


\section{References}

Agbejule, A., \& Saarikoski, L. (2006). The effect of cost management knowledge on the relationship between budgetary participation and managerial performance. The British Accounting Review, 38(4), 427-440. https://doi.org/10.1016/j.bar.2006.06.003

Arifuddin, Azis, F., \& Kusumawati, A. (2017). Participation and goal clarity budget to performance apparatus with commitment and cultural organization as a moderating variable. World Journal of Social Sciences, $7(2), 24-37$.

Blumberg, M., \& Pringle, C. D. (1982). The missing opportunity in organizational research: Some implications for a theory of work performance. The Academy of Management Review, 7(4), 560-569.

Boujelbene, M. A., \& Affes, H. (2015). Impact of environmental uncertainty on the relationship between budgetary participation and managerial performance and job satisfaction: Some Tunisian evidence. International Journal of Accounting and Finance, Inderscience Enterprises Ltd, 5(1), $27-47$.

Brink, A. G., Coats, J. C., \& Rankin, F. W. (2018). Who's the boss? The economic and behavioral implications of various characterizations of the superior in participative budgeting research. Journal of Accounting Literature, 41, 89-105. https://doi.org/10.1016/j.acclit.2018.03.004

Cheng, K., Chen, T., \& Shih, N. (2014). The influence of budgetary participation by R\&D managers on product innovation performances: The effect of trust, job satisfaction and information asymmetry. Asia Pacific Management Review, 19(2), 133-150. https://doi.org/10.6126/APMR.2014.19.2.02

Chong, V. K., \& Strauss, R. (2017). Participative budgeting: the effects of budget emphasis , information asymmetry and procedural justice on slack - Additional evidence. Asia-Pacific Management Accounting Journal, 12(1).

Colquitt, J. A., LePine, J. A., \& Wesson, M. J. (2017). Organizational behavior: Improving performance and commitment in the workplace (5th ed.). McGraw-Hill Education.

Derfuss, K. (2016). Reconsidering the participative budgeting-performance relation: A meta-analysis regarding the impact of level of analysis, sample selection, measurement, and industry influences. The British Accounting Review, 48(1), 17-37. https://doi.org/10.1016/j.bar.2015.07.001

Ernis, F., Sularso, R. A., \& Wardayati, S. M. (2017). Pengaruh partisipasi anggaran terhadap kinerja manajerial melalui komitmen organisasi dan motivasi. Jurnal Bisnis Dan Manajemen, 11(2), 139-154.

Farahmita, A. (2016). Job satisfaction, cost management knowledge, budgetary participation, and their impact on performance. International Research Journal of Business Studies, 9(1), 15-29.

Ghozali, I., \& Latan, H. (2017). Partial Least Squares: Concepts, Methods and Applications using WarpPLS 4. Badan Penerbit Undip.

Gunawan, A. C., \& Santioso, L. (2015). Pengaruh partisipasi anggaran terhadap kinerja motivasi sebagai variabel moderating (studi empiris pada perusahaan manufaktur di Jakarta dan Tangerang). Jurnal Akuntansi, 19(1), 144-159.

Hariyanti, W., Purnamasari, P., \& O, M. L. (2015). Pluriform motivation as antecedent and its relationships to budgeting participation and managerial performance ( empirical study on manufacturing companies listed on Indonesian stock exchange ). Procedia - Social and Behavioral Sciences, 211, 836-843. https://doi.org/10.1016/j.sbspro.2015.11.110

Hasan, H., Bz, F. S., \& Indriani, M. (2018). The role of budgetary control on managerial performance in fertilizer companies in Indonesia. Journal of Accounting Research, Organization, and Economics, 1(2), 138-148.

Hunton, J., Wright, A., \& Wright, S. (2001). Business and audit risks associated with ERP systems: Knowledge differences between information systems audit specialists and financial auditors. Fourth European Conference on Accounting Information Systems (ECAIS), Athens, 1-40.

Indriani, M., \& Nadirsyah. (2015). Interaction effect of budgetary participation and management accounting system on managerial performance: Evidence from Indonesia. Global Journal of Business Research, 9(1), $1-13$.

Irfan, M., Santoso, B., \& Effendi, L. (2016). Pengaruh partisipasi anggaran terhadap senjangan anggaran dengan asimetri informasi, penekanan anggaran dan komitmen organisasional sebagai variabel pemoderasi. Jurnal Akuntansi Dan Investasi, 17(2), 158-175. https://doi.org/10.18196/jai.2016.0052.158-175 
Jermias, J., \& Yigit, F. (2013). Budgetary participation in Turkey: The effects of information asymmetry, goal commitment, and role ambiguity on job satisfaction and performance. Journal of International Accounting Research, 12(1), 29-54. https://doi.org/10.2308/jiar-50385

Karakoc, E. Y., \& Ozer, G. (2016). The budget-related antecedents of job performance. International Journal of Research in Business \& Social SCience, 5(3), 38-53. https://doi.org/10.9761/jasss

Lameira Silva, O. L., Macedo, A. R. G., Nunes, E. do S. C. de L., Campos, K. D., Araújo, L. C. C., Tiburço, X., Pinto, A. S. O., Peixoto Joele, M. R. S., da Silva Ferreira, M., da Silva, A. C. R., Raices, R. S. L., da Cruz, A. G., Juen, L., \& da Rocha, R. M. (2020). Effect of environmental factors on the fatty acid profiles and physicochemical composition of oysters (Crassostrea gasar) in Amazon estuarine farming. Aquaculture Research, 51(6), 2336-2348. https://doi.org/10.1111/are.14577

Lau, C. M., Scully, G., \& Lee, A. (2018). The effects of organizational politics on employee motivations to participate in target setting and employee budgetary participation. Journal of Business Research, 90, 247-259. https://doi.org/10.1016/j.jbusres.2018.05.002

Mahoney, T. A., Jerdee, T. H., \& Carroll, S. J. (1965). The job(s) of management. Industrial Relationships, 4(2), $97-110$.

Maiga, A. S., Nilsson, A., \& Jacobs, F. A. (2014). Assessing the impact of budgetary participation on budgetary outcomes: the role of information technology for enhanced communication and activity-based costing. Jounal of Management Control, 25(1), 5-32. https://doi.org/10.1007/s00187-014-0191-9

Mercurio, Z. A. (2015). Affective commitment as a core essence of organizational commitment: An integrative literature review. Human Resource Development Review, 14(4), 1-26. https://doi.org/10.1177/1534484315603612

Milani, K. (1975). The relationship of participation in budget-setting to industrial supervisor performance and attitudes: A field study. The Accounting Review, 50(2), 274-284.

Mowday, R. T., Steers, R. M., \& Porter, L. W. (1979). The Measurement of Organizational Commitment. Journal of Vocational Behaviour, 14(2), 224-247.

Murwaningsari, E. (2008). The role of organizational commitment and procedural justice in moderating the relationship between budgetary participation and managerial performance. Gadjah Mada International Journal of Business, 10(2), 185-210.

Noor, I. H., \& Othman, R. (2012). Budgetary participation: How it affects performance and commitmen. Accountancy Business and the Public Interest, 53-73.

Nuraini, A. L., \& Rosyati. (2012). Pengaruh partisipasi anggaran dan informasi akuntansi terhadap kinerja manajerial: Komitmen organisasi, gaya kepemimpinan, ketidakpastian tugas, ketidakpastian lingkungan, dan strategi bisnis sebagai variabel moderasi. Conference In Business, Accounting and Management, $1(1), 99-120$.

Oluwalope, A. A., \& Sunday, O. (2017). Impact of budgetary participation and organizational commitment on managerial performance in Nigeria. Accounting and Finance Research, 6(3), 48-55. https://doi.org/10.5430/afr.v6n3p48

Oyewo, B., \& Adyeye, G. (2018). Budgetary participation and managerial performance in public sector organisations: A study from Nigeria. Economic Series, 5(1), 86-96.

Patterson, M. G., West, M. A., Lawthom, R., \& Nickel, S. (2003). Impact of people management practices on organizational performance (pp. 1-39). Institute of Personnel and Development.

Porter, L. W., Steers, R. M., \& Mowday, R. T. (1974). Organizational commitment, job satisfaction, and turnover among psychiatric technicians. Journal of Applied Psychology, 59(5), 603-609.

Robbins, S. P., \& Judge, T. A. (2017). Organizational Behavior (17th ed.). Pearson Education, Inc.

Rokhman, M. T. N. (2017). Improving managerial performance through participation role of budget preparation: A theoretical and empirical overview. Journal of Economics and Finance, 8(1), 39-43. https://doi.org/10.9790/5933-0801013943

Rudhianto, H. (2010). Pengaruh Komitmen Organisasi dan Gaya Kepemimpinan terhadap Hubungan antara Partisipasi Anggaran dan Kinerja (Studi Empiris di Universitas Sebelas Maret). Universitas Sebelas Maret Surakarta. 
Santos, A. C. dos, Lavarda, C. E. F., \& Marcello, I. E. (2014). Relationship between cost management knowledge and budgetary participation with managers ' performance. Review of Business Management, 16(50), 124-142. https://doi.org/10.7819/rbgn.v16i50.1236

Saraswati, G. P., \& Aisyah, M. N. (2015). Pengaruh partisipasi penyusunan anggaran terhadap kinerja manajerial dengan job relevant information sebagai variabel moderating ( studi pada dinas pemerintah kota Yogyakarta ). Jurnal Nominal, 4(2), 136-147.

Savitri, E., Ritonga, K., \& Ayuni, R. (2015). Pengaruh partisipasi anggaran terhadap kinerja manajerial dengan kepuasan kerja dan pengetahuan manajemen biaya sebagai variabel moderating. Jurnal Ilmiah Ekonomi Dan Bisnis, 12(2), 166-181.

Selvina, M., \& Yuliansyah, Y. (2015). Relationships between Budgetary Participation and Organizational Commitment: Mediated by Reinforcement Contingency Evidence from the Service Sector Industries. International Research Journal of Business Studies, 8(2), 69-80.

Shields, J. F., \& Shields, M. D. (1998). Antecedents of Participative Budgeting. Accounting, Organizations and Society, 23(1), 49-76.

Shields, M. D., \& Young, S. M. (1994). Managing innovation costs: A study of cost conscious behavior by R\&D professionals. Journal of Management Accounting Research, 6(1), 175-196.

Sumarno, J. (2005). Pengaruh komitmen organisasi dan gaya kepemimpinan terhadap hubungan antara partisipasi anggaran dan kinerja manajerial (studi empiris pada kantor cabang perbankan Indonesia di Jakarta). Jurnal Bisnis Strategi, 14(2), 197-210.

Wombacher, J. C., \& Felfe, J. (2017). Dual commitment in the organization: Effects of the interplay of team and organizational commitment on employee citizenship behavior, efficacy beliefs, and turnover intentions. Journal of Vocational Behavior, 102, 1-14. https://doi.org/10.1016/j.jvb.2017.05.004

Wong-On-Wing, B., Guo, L., \& Lui, G. (2010). Intrinsic and extrinsic motivation and participation in budgeting : Antecedents and consequences. Behavioral Research in Accounting, 22(2), 133-153. https://doi.org/10.2308/bria.2010.22.2.133

Yogantara, K. K., \& Wirakusuma, M. G. (2013). Pengaruh komitmen organisasi dan gaya kepemimpinan pada hubungan antara partisipasi anggaran dan kinerja manajerial BPR. E-Jurnal Akuntansi Universitas Udayana, 4(2), 261-280.

Yuliansyah, Y., \& Khan, A. A. (2017). A revisit of the participative budgeting and employees' self-efficacy interrelationship - empirical evidence from Indonesia's public sector. International Review of Public Administration, 22(3), 213-230. https://doi.org/10.1080/12294659.2017.1325584

Zainuddin, S., \& Zainal, D. (2012). The impact of intrinsic and extrinsic motivation on job performance in a participative budget setting : A research note. Journal of Accounting Perspectives, 5, 48-58. 